\title{
Beyond reproduction: what is silenced and what is voiced matters - narratives of an online WhatsApp community; a Kuwaiti experience
}

\author{
Khadija Al-Ali \\ Associate Professor \\ Public Authority of Applied Education and Training \\ College of Basic Education \\ Department of Educational Technology \\ ky.alali@paaet.edu.kw
}




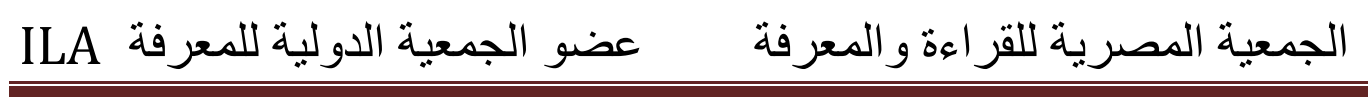




\section{الجمعية المصرية للقر اعة والمعرفة عضو الجمعية الدولية للمعرفة ILA}

\section{Abstract}

This article examines the dynamics of silence in an online WhatsApp community. I analyse the written text of an incident of exchanged messages amongst my departmental members in a Kuwaiti higher education college. I tell a story of an old-timer who remained silent during the incident and throughout the year. Based on a feminist research approach and Fivush's (2010) framework on silence, I show how place, power and voice interconnect in a dynamic way. I also discuss how silence can be used as a tactful strategy and a resistance tool. In this respect silence is powerful and voice is powerless.

Keywords: Silence, voice, power, place, online communities, Kuwaiti college
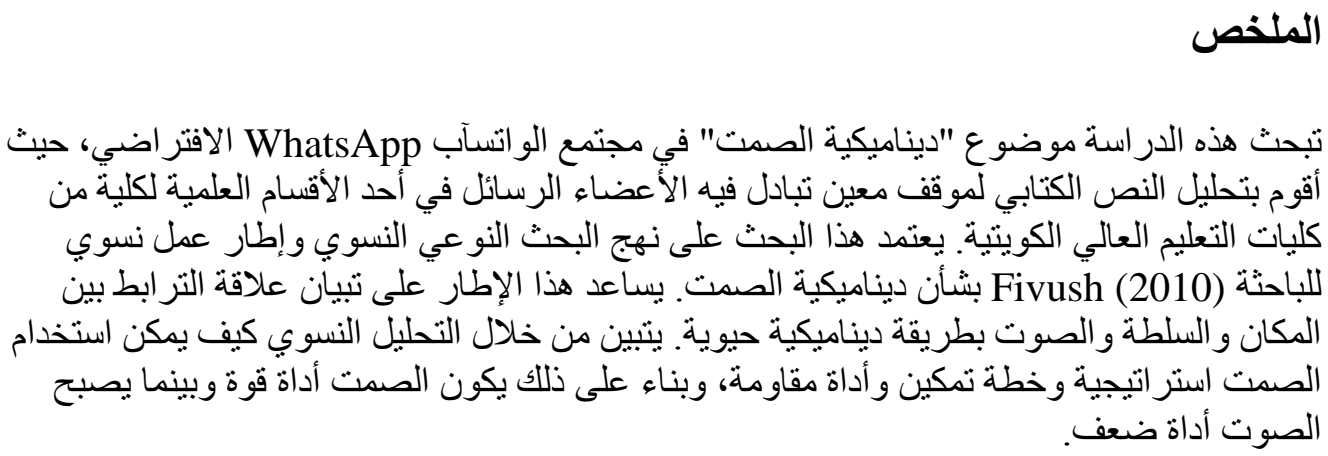


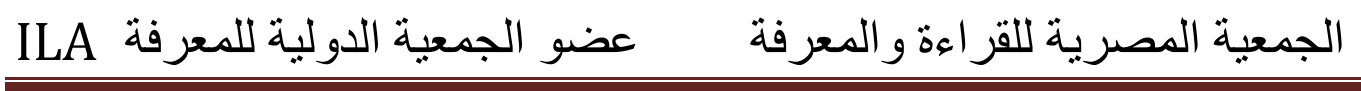

\section{Introduction}

In this study, I explore the dynamics of silence in an online text-based communication amongst members of a WhatsApp community in my departmental workplace in the Kuwaiti college. I address the following question: how can silence be understood in the light of power within a community of practice $(\mathrm{CoP})$ ? To answer this question, I posit these two sub-questions: How can silence empower marginalised members of the community? How can marginalised members use silence as a strategy to exercise power over the dominant? I approach this study from a feminist perspective on research. Using Fivush's (2010) work, I investigate how place, power and silence interconnect in a dynamic way.

Silence is generally recognised as loss of power. It is a challenging subject. It is even more challenging when exploring the silence of tutors because it puts an authority figure in an 'assumed powerless' position. This study gives me the opportunity to deepen my understanding and confront my preconceptions towards silent members of the community. Following this, I briefly introduce feminist research and discuss the concepts of voice and silence. I then examine Fivush's (2010) framework to view how place, power and voice interconnect. Subsequently, I attend to the other face of stability and cohesion in communities. I introduce the context and this study in the section to follow. I end the paper with an analysis of the WhatsApp story, followed by a discussion and conclusion.

\section{Feminist research and the dynamics of silence}

The statement: 'the personal is political' is at the heart of feminist research. It accentuates personal experience as a valid source of knowledge; a kind of 'inner knowing' (Weiler, 1992). Experience is lived, and if something is lived and felt then it is real for the person experiencing it (Stanely and Wise, 1993). Feminist research clearly stands in opposition to mainstream positivist research and challenges the value-neutral, objective, socially impartial approach to inquiry and research (Harding, 1992). In fact, research relations premised on positivism is seen as a situation of dominance (Mies, 1994). There are different stands of feminist research and they all unite on the authority of experience. In authorising experience, feminist researchers seek to empower and grant voice to the voiceless, particularly women. Hence the concepts of experience, voice, and 
(em)power(ment) are central to feminist research and thought. It is difficult to find an agreed definition for the terms; in fact, they seem to be taken as selfexplanatory concepts (Lazreg, 2012), which opens a heated debate around them.

Voice is used as a metaphor which implies a strategy to empower and advance 'horizontal power with' rather than 'hierarchical power over' (Kenway and Modra, 1992). Here, one model of power as dominance 'over' is replaced with another model of power as energy 'with' (Liao, 2006; Shrewsbury, 1997). Moreover, the physicality of voice is aspired. Those who speak, and have a voice, are empowered and therefore have the power to change. Those who are silent are seen as powerless and oppressed. The dichotomised view is built on an either/or logic which is ahistorical, decontextualised and abstract. As such, feminists' construction of voice and silence is trapped in an opposition, creating a dualism of a favoured voice compared to a demeaned silence. Consequently, voice is always seen as powerful and silence as powerless (Orner, 1992). This binary structure is simplistic and locks the two concepts in a hierarchical relationship preventing other forms of understandings to emerge. Simply put: it evades the interrelatedness of the terms and the complexity of real-life situations and experiences. Feminist critics argue against this binary system (Mishra, 2013; Mohanty, 1986). Instead, they assert the importance of situating individuals socially, culturally, geographically, and historically. That is, people's local context and trans-local context matter in understanding their experiences and stories (Curnow, 2016).

Those who view silence with a singular meaning ignore the shifting relations of power and the profound contextual nature of interaction (Orner, 1992). Hence, place, power and silence/voice interconnect, and are imperative for a feminist analysis on the dynamics of silence (Fivush 2010). Women's silence is shown to be used as both a strategy and a survival tool (Lazreg, 2012; Lewis, 1994; Parpart, 2013). Using silence as power is not limited to women, it is also used by marginalised men. However, research on silent men is lacking (Carter, 2006). The current paper attempts to address this shortage with a view based on constructivism as an ontological position. That is to say, social actors are constantly engaged in producing and revising meaning through social interaction (Grix, 2010), and that meaning is inherently socially negotiated (Lave, 1991). Accordingly, a qualitative feminist methodological approach is adopted to investigate a man's silence. To my knowledge, this study is unique because the research approach is feminist, the subject is male, the context is online Kuwaiti WhatsApp community. 


\section{الجمعية المصرية للقر اعة والمعرفة عضو الجمعية الدولية للمعرفة}

To understand how the three concepts of silence, place and power interconnect, I turn next to the work of Robyn Fivush.

\section{'But what about what is not said?' A framework for understanding silence}

I rely mainly on Fivush (2010), and her other work, to provide a framework for understanding voice and silence. Fivush (2010) explains that silence and voice are socially constructed in conversational interactions and therefore, are negotiated, imposed, and contested. To understand voice and silence, local conversations must be understood within cultural and social frameworks that shape life and embrace canonical narratives which are both normative and prescriptive. Situated local experiences conform or deviate from those canonical narratives creating specific spaces for voice and silence. Fivush (2010) argues that as narratives emerge within social interactions, so do certain events, interpretations and evaluations of those events. The telling and retelling seals those narratives as accepted (or contested) evaluative versions of the past.

According to Fivush (2010), individuals are situated in particular places within cultural and historical frameworks. In those places, certain aspects of the individual such as race, gender and class are valued in particular ways, and individuals are defined as particular kinds of persons (Fivush, 2006). So, they are denied and provided certain aspects of experience and certain ways of knowing. Any change in one's place changes one's access to certain experiences and the interpretation of those experiences (Fivush and Marin, 2007). Hence Fivush (2010) asserts that place determines power and power determines voice. For Fivush (2006), 'place' "is a dynamic concept; one's historical, cultural, and situational position in an ongoing stream of human activity is always evolving" (p. 2).

Furthermore, those individuals who are in roles of power can shape the shared narratives. Shared narratives provide 'authority to define' appropriate narrative, and the 'power to validate' certain narratives over others. Accepted shared narratives are considered the centre and are given voice while other narratives appear silenced at the margin, and from this standpoint power gives voice (Fivush, 2004; 2006). Power also emerges from a theoretical analysis that experience is situated within cultural, social, and historical context (Fivush and 
Marin, 2007). For Fivush (2010), power is dynamic; it is always in process and occurs over time: "power is negotiated, imposed, taken, and given" (p. 90). Power is also a relational structure. Therefore, silence and voice must be conceptualised within evolving power structures and relations in an ongoing dialectic interaction. There are multiple levels of accepted and contested narratives within a group (Fivush, 2010). They co-exist and influence each other, with the most powerful narrative being the culturally dominant one. Resistance narratives are shared by members of the marginalised groups. These narratives create spaces for shared history and challenge dominant narratives. Therefore, marginalised groups are "speaking through silence" (Fivush, 2010, p. 93), and in this way silence can be powerful. By establishing their resistance narratives, marginalised members are telling their stories from their own perspective and maintaining control over them.

To sum up then, Fivush's framework (2010) dismantles the dichotomous structure of silence and voice. It accentuates that place, power and silence interconnect in a dynamic way. When we view 'place' in the light of difference and social distinction, and when we focus on "...how the boundaries and transitions are encountered and defined" (Brewer and Nourish, 2008, p. 3), then we are able to unfold how dominant narratives are normalised and become the standpoint of participants in dominant places. By the same token, we are also able to unfold how marginalised narratives become resistance narratives. Only then can the interconnectedness of the three concepts become clear, and further expand our understanding of the synergistic relationship between silence and voice.

Next, I briefly introduce CoP in order to pave way for the Kuwaiti online community, where the dynamics of silence is examined.

\section{The other face of stability; communities in conflict}

Although some may think it is difficult to define the term CoP (Agrifoglio, 2015), Weneger (2010) simply explains that it "is the simplest social unit that has the characteristics of a social learning system" (p. 180). It is a constituent element and a point of entry of a broader conceptual framework (Wenger, 1999). Elsewhere, Wenger-Trayner and Wenger-Trayner (2015) indicate that $\mathrm{CoP}$ "are groups of people who share a concern or a passion for something they do and learn how to do it better as they interact regularly" (p. 1). Learning 
occurs by observation, absorption, integration and peripheral participation between newcomers and old-timers of the community. The movement in the community is towards full participation. As such, the vivid simplicity of the description masks conflicts, relations of power and power dynamics (Kakavelakis and Edwards, 2011). In fact, mainstream readings on CoP are identified by their emphasis on "social cohesion" relying on relations of 'cooperation and subordination' (Kakavelakis and Edwards, 2011, p. 475). The multiplicity of actors engaged in activity seems to portray active accepted "habitualised practices" (Kakavelakis and Edwards, 2011, p. 476) and involvements through their interdependencies and social relationships (Lave, 2009).

Critical accounts draw attention to the ongoing dynamic and unfolding processes of relations (Hansman and Wilson, 2002; Kakavelakis and Edwards, 2011). Therefore, researchers, such as Kerno (2008), accentuate the need to understand $\mathrm{CoP}$ in the light of their limitations. Still, others have shown growing concern with regards to the stable character of the community (Fuller, Hodkinson, Hodkinson, \& Unwin, 2005). Fuller et al. (2005) assert that power is inherent in community relations leading to control of and constraints to resources and hence learning opportunities. Further, Curnow (2016) argues that there is an assumption that all participants "will believe and adopt the same narratives... or be able to enact forms of participation in the same way" (p. 219). This view erases the experiences of marginalisation and the subjugated knowledges that some (non-dominant) members bring with them based on their social locations. Curnow (2016) stresses that moving towards full participation is not equally available to members of the community. She asserts that members' social locations impact their movement to full participation. Moreover, Salminen-Karlsson (2006) explains that power is not distributed equally in CoP. Indeed, members with powerful positions use their power in different ways; against the benefit of others and to marginalise them. She also asserts that societal gender relations and power systems are present in any $\mathrm{CoP}$. Members therefore not only learn the gender order and the power invested within (Salminen-Karlsson, 2006), but also how to perform a task in a gender appropriate way (Paechter, 2003).

In brief, there are always conflicts of power just as there are also uniformity and stability in CoP (Lave, 2009). Therefore, exploring the social contexts, and understanding how actors enact social relations and confront conflicts will pave the way to unfolding the complexity of practices, and understanding how the 


\section{الجمعية المصرية للقر اعة والمعرفة عضو الجمعية الدولية للمعرفة ILA}

places that actors occupy become expressions of power and how power then ties to silence in a dynamic way.

\section{Contextualising self}

My focus in this study is on one incident of a year-long chat amongst departmental teaching staff members of a WhatsApp group in the College of Basic Education where I work. According to Farnsworth, Kleanthous and Wenger-Trayner (2016), a social theory is a tool for constructing a certain type of narrative. From this perspective I embark on this venture to investigate the online textual narrative. This online community was created almost two years before I joined in March 2017. It had three main characteristics of a CoP: shared domain of interest related to the field of educational technology; members who engage in joint activities and discussions; and a shared inventory of resources (Wenger, 1999). My departmental online community was active on a daily basis; there was always something new to share or a concern to address, official information regarding the department and the collegiate were also dispatched. On the surface, it seemed to be 'stable' and 'coherent' (Lave, 2009).

When I joined, there were 26 teaching staff members - seven of those were newcomers with less than two years' experience. The rest were old-timers from face-to-face community that I knew. Five old-timers refused to join the online community. Their refusal was a result of their disagreement with the female department head (DH). My situation was unique as I was both a returning oldtimer, and a newcomer to the virtual community.

For the purpose of this research, a message was dispatched to the WhatsApp group seeking approval for using the textual exchanges as data for this research paper. When all participants agreed and stated their consent, the textual history of a year-long WhatsApp communication was printed. It was carefully read to identify incidents of conflict within the online community. The incidents were then reviewed in order to choose one that would be the focus of this paper. The textual conversation of the incident was then translated to English using 'Google Translate' (Google Inc., 2018). This incident was chosen for the challenges it represented, the powerful long episodes of silences and, ironically, the powerful succinct mishaps of voice. 


\section{الجمعية المصرية للقر اعة والمعرفة عضو الجمعية الدولية للمعرفة}

\section{The story: 'on the fence and beyond'}

This story is about 'Fareed', a male old-timer of the online community who remained silent throughout the year. I present this narration from my own perspective. As such, I am aware that this textual device retains my authority. The overall story is told in a chronological order and as I experienced the unfolding online textual events. To help construct the story I repeatedly asked: "how do the different places that members of the CoP occupy become expressions of power? How does power then tie to silence/voice in a dynamic way? This helped me recognise the shifting/multiple places members occupy, deduce how power appeared to be invested in those particular places, and delineate how silence/voice seemed to tie to power in those specific places. The different textual parts quoted were chosen because they strongly represent the interplay between place, power and silence. This story is my interpretation of the relationship between place, power and silence. All names used in my story are pseudonyms. All events occurred online.

The incident I explore occurred a month after I joined the online WhatsApp community. It started with Fareed sending a message naming the sender of the previous message. For me it was an odd thing to do. Yet no one commented. And the online communication continued as usual. But, I kept my thoughts silent. A week later Leila, the $\mathrm{DH}$, sent an official request asking all teaching staff to refrain from involving administrative staff in teaching or activities related to it. She reminded us that it was against the rules and regulations of the college and the Public Authority of Applied Education and Training (PAAET), to which our college belongs. She added:

"You will receive a copy of this message by email momentarily. Those of you who have not yet provided us with your emails are still held accountable. Those in violation of these regulations will face appropriate sanctions"

No one commented, no email was sent, and the online communication carried on as usual. But I was disturbed by the choice of words; I found them rigid and threatening. Yet I kept my thoughts silent. Two days later, Ali, a male old-timer, sent an online link of a newspaper article about allegations of forgery regarding students' grades in our department. The heading read: "The Department of Educational Technology changes the final grades of women students". The allegation, the person(s) behind it, and the fact that it was publicised in the daily newspaper stirred a heated controversy within the online community. One 
person that was responsible, an administrative member, was named by $\mathrm{DH}$. But the online discussion revealed he did not act alone, there were other old-timers from the teaching staff who were also involved. The exchange of words also revealed that the allegation, in essence, was accurate, albeit the grades were reviewed by a committee upon a formal complaint from the students. The communicated text amongst the members reflected a deep hostility towards the individual(s) allegedly responsible and a profound division in the community. For example, Noora, a female old-timer wrote:

"I think this matter should be taken to court to defend the reputation of the members and that of the Department"

While Hamad, a male newcomer, said:

"It is DH's duty to respond and follow official procedures regarding this person. The Department now is remarkably stable, but there are those who try to cause trouble. So, it is the DH's duty to annihilate the entire serpent and not just part of it"

The departmental community was far from stable. The thought of 'taking colleagues to court' to settle workplace disputes, and the use of the 'serpent' metaphor, which denotes threat and danger within the Kuwaiti context, to describe colleagues were signs of confusion and turmoil within the community. Above all, this reflected the power that the dominant discourse was based on.

Towards the end of the online communication, Faisal, a male newcomer said:

"I am totally confident that everything that has been discussed here will be leaked. And another complaint will be filed. So, DH expect a complaint in the near future, of course it will be written by his 'genius knowledgeable advisor' (who advised him to seek the media)"

The discussion ended with a warning from Ali to whomever "dares to disclose" the private conversation.

Two weeks later Fareed re-sent a series of previously posted messages, naming the sender of each message. It became clear to me that his messages were meant for (an)other individual(s). It all made sense. I understood then that Fareed was the person targeted as the 'informant' and possibly the 'advisor'. I also 
understood that all members of the online community knew about Fareed's involvement in 'leaking and disclosing' the private conversation, to his friend(s) who refused to join the online community. Immediately after receiving the messages re-sent by Fareed, the DH started signing her name at the end of each message she sent; as did everyone else, for some time. It was a confrontational note to Fareed indicating that 'We' knew what was going on. But 'We' too participated in 'leaking and disclosing' the private conversation, whether faceto-face or by other means. Yet Fareed was penalised for it. Nonetheless, Fareed was not deterred; he firmly sat on the fence, as both an insider and outsider of the online community. Once in a while a 'mishap' appeared, and a message was re-sent reminding us that he was still there.

\section{Silence: power in disguise}

The canonical narrative in the Kuwaiti online community is already established. Here, it is represented by $\mathrm{DH}$, a position of authority, and the majority of the members of the community, old and new. The dominant narrative has certain rules, specific words and descriptions, and fixed ways of operating. It seems to be in alignment with and abides to the larger framework of the college and PAAET within which it is situated. DH's online voice is heard from a powerful place urging members to conform, reminding them of rules and regulations as well as sanctions. Those who conform follow in the same vein confronting silent members and accusing them of distorting the 'stable' community; adopting the same narrative and participating in the same way (Curnow, 2016). Dominant shared narrative is always in the process of negotiation with dominant members suggesting strategies to deal with conflicts, suppress dissenting voices and establish desired stability (Carter, 2006). The position of the old-timer or newcomer does not seem to affect voice or silence. It is, it seems, the affiliation with the authority figure that identifies a member as powerful or powerless. Oppositional voices are denied the ability to participate, forced to withdraw, and in effect, they are being silenced in a "simple and perfect" manner of silencing (Carter, 2006, p. 218; Fivush, 2010).

Referring to Fivush's (2010) theoretical framework and the dynamic interplay between power, place and silence, it becomes clear that this is not a dichotomous structure of power wherein those who have power versus those who are powerless. To view power as dichotomous means that the same identical binary structure of power will always be reproduced; for everyone who 
has power there is always another who has no power. The danger of this binary structure is that it erases all modes of resistant experiences (Mohanty, 1986), such as Fareed's. And "Resistance can thus only be defined as cumulative reactive, not as something inherent in the operation of power" (Mohanty, 1986, p.352). Fareed's powerful silence dismantles the binary structure. Unlike other members of the marginalised group, Fareed did not leave the online community. His insistence to remain is powerful. Fareed does not 'formally' participate, yet he is 'informally' active. He represents 'other' discontent members; he is their voice. Fareed can be seen as the "outsider within" (Collins, 1986, p. 514): a unique standpoint that gives him insight to both sides. This distinctive place grants him entrance to the dominant community as an outsider, and the marginalised community as an insider. Amazingly, Fareed could be seen as a legitimate member of the two (oppositional) communities. He also participates in shaping and re-shaping the dominant as well as the marginalised narratives.

In essence then, there is an 'other' marginalised online community which feeds on the 'shared' narrative of the main community and accordingly produces its own 'resistance' narrative. What is important to note is that each acknowledges the existence of the other and uses that knowledge to its own benefit. They coexist and influence each other (Fivush, 2010). DH and dominant members use their online discourse to inform (rules and regulations), attack (annihilate the entire serpent), threaten (dares to disclose) and sarcastically demean (genius knowledgeable advisor) other marginalised members through Fareed. Facing a dominant coalition and culture which crushes oppositional voice (Blackman and Sadler-Smith, 2009), Fareed decides to remain silent. His online silence seems to be strategic and a resistance tool (Carter, 2006).

Still, the marginalised community is a step ahead; through Fareed, it has access to the dominant discourse. Masked by his online silence, Fareed is invisibly active. His sudden online appearances, even if accidental, could be read as messages affirming his place, power, and voice and reminding us of his powerful silence. Fareed chooses to remain silent and chooses when to participate, through seemingly 'sudden loud bursts' - it is an ongoing struggle. Although there are assigned places of power, Fareed manages to create his exclusive place. In fact, Fareed appears to be most powerful 'fence-sitter' of the two communities.

In all, Fivush's (2010) theoretical framework is useful in providing a strong lens through which silence is seen as powerful. Marginalised members of CoP use 
silence as a tactful strategy and a tool for resistance. Silence is powerful because it is calculated. While dominant groups of the community write and rewrite their shared narratives, they are compelled (by the marginalised) to voice their disapproval, hence voice can be seen as powerless because it is demanded (Carter 2006). Marginalised groups need not; they are free to be silent, in this sense silence is powerful and liberating (Fivush, 2010).

\section{Conclusion and implications}

The purpose of my study is to explore other interpretations of silence and silent members of CoP, which defy the norm. Using a feminist approach to research, and Fivush's analytical framework of the dynamic interconnection between place, power and silence an 'Other' interpretation is offered; accordingly, an 'Other' image of the community emerges. I started my research with these questions: how can silence be understood in the light of power within a community of practice $(\mathrm{CoP})$ ? How can silence empower marginalised members of the community? How can marginalised members use silence as a strategy to exercise power over the dominant? I have shown that silence is strategically used by marginalised members of the community forcing dominant members to voice their discontent and rewrite the shared narrative. Although there are assigned powerful places in the community, marginalised members seem to create their own places and exercise power through strategic silence.

This has been a liberating piece of research for me. It helped me confront my prejudices and challenge my preconceptions regarding silence and most importantly silent men. To use a feminist approach to understand a man's silence and give him voice could be seen as incongruous, or perhaps a conflict of interest. I see it as opening up feminist research's horizon to include oppressed men, and silenced/silent men's experiences. I have also become aware of the danger of oppositional binaries which reduces life experiences. The $\mathrm{CoP}$ approach, coupled with feminism, though was limited to one incident and story of the WhatsApp community, has opened up a different interpretation of my experience of silent others. This research is based on my interpretation, and thus carries with it my partial view; but it can be further enriched by including marginalised members' experiences and their interpretations of those experiences. Further in-depth studies are needed in this area to understand how silence relates to and affects the learning and progression of all members of the community. 


\section{References}

Agrifoglio, R. (2015). Knowledge Preservation Through Community of Practice: Theoretical Issues and Empirical Evidence: Springer.

Blackman, D., \& Sadler-Smith, E. (2009). The Silent and the Silenced in Organizational Knowing and Learning. Management Learning, 40(5), 569-585. doi: 10.1177/1350507609340809

Brewer, J., \& Dourish, P. (2008). Storied spaces: Cultural accounts of mobility, technology, and environmental knowing. International Journal of Human-Computer Studies, 66(12), 963-976. doi: https://doi.org/10.1016/j.ijhcs.2008.03.003

Carter, R. (2006). Of things said and unsaid: Power, archival silences, and power in silence. Archivaria, 61(19).

Collins, P. (1986). Learning from the Outsider Within: The Sociological Significance of Black Feminist Thought. Social Problems, 33(6), S14S32. doi: $10.2307 / 800672$

Curnow, Joe. (2016). Situated Learning, Situated Knowledge: Situating Racialization, Colonialism, and Patriarchy Within Communities of Practice: Singapore: International Society of the Learning Sciences.

Farnsworth, V., Kleanthous, I., \& Wenger-Trayner, E. (2016). Communities of Practice as a Social Theory of Learning: a Conversation with Etienne Wenger. British Journal of Educational Studies, 64(2), 139-160. doi: 10.1080/00071005.2015.1133799

Fivush, R. (2004). Voice and silence: A feminist model of autobiographical memory. The development of the mediated mind: Sociocultural context and cognitive development, 79-99. Retrieved from http://www.psychology.emory.edu/cognition/fivush/voice\%26silence.pd $\mathrm{f}$ 
Fivush, R. (2006). Voice and Silence in Autobiographical Narratives. Reading On: A Journal of Theory and Criticism, 1, 1-17.

Fivush, R. (2010). Speaking silence: The social construction of silence in autobiographical and cultural narratives. Memory, 18(2), 88-98.

Fivush, R., \& Marin, K. (2007). Place and power: A feminist perspective on self-event connections. Human Development, 50(2-3), 111-118.

Floding, M., \& Swier, G. (2012). Legitimate peripheral participation: Entering a community of practice. Reflective practice: Formation and supervision in ministry, 31 .

Fuller, A., Hodkinson, H., Hodkinson, P., \& Unwin, L. (2005). Learning as Peripheral Participation in Communities of Practice: A Reassessment of Key Concepts in Workplace Learning. British Educational Research Journal, 31(1), 49-68. doi: doi:10.1080/0141192052000310029

Google. (2018). Google Translate. Retrieved from https://translate.google.co.uk/ Grix, J. (2010). The foundations of research: Macmillan International Higher Education.

Hansman, C., \& Wilson, A. (2002). Situating Cognition: Knowledge and Power in Context.

Harding, S. (1992). Rethinking standpoint epistemology: What is" strong objectivity?". The Centennial Review, 36(3), 437-470.

Kakavelakis, K., \& Edwards, T. (2012). Situated learning theory and agentic orientation: A relational sociology approach. Management Learning, 43(5), 475-494.

Kerno Jr, S. J. (2008). Limitations of communities of practice: a consideration of unresolved issues and difficulties in the approach. Journal of Leadership \& Organizational Studies, 15(1), 69-78.

Lave, J. (1991). Situating learning in communities of practice. Perspectives on socially shared cognition, 2, 63-82. 
Lave, J. (1993). The practice of learning. In J. Lave \& S. Chaiklin (Eds.), Understanding Practice: Perspectives on Activity and Context (pp. 3-32). Cambridge: Cambridge University Press.

Lave, J. (2009). The practice of learning. Contemporary theories of learning: Learning theorists... in their own words, 200-208.

Lazreg, M. (2012). Women's Experience and Feminist Epistemology: A critical neo-rationalist approach Knowing the Difference (pp. 59-76): Routledge.

Lewis, M. G. (1993). Without a word: Teaching beyond women's silence: New York, NY: Routledge.

Liao, H-A. (2006). Toward an epistemology of participatory communication: a feminist perspective. The Howard Journal of Communications, 17(2), 101-118.

Luke, C., \& Gore, J. (1992). Feminisms and critical pedagogy.

Mies, M. (1993). Towards a methodology for Feminist research. In M. Hammersley (Ed.), Social research: Philosophy, politics and practice. London; Newbury Park, Calif.: Sage Publications.

Mishra, R. K. (2013). Postcolonial feminism: Looking into within-beyond-to difference. International Journal of English and Literature, 4(4), 129134.

Mohanty, C. T. (1984). Under Western eyes: Feminist scholarship and colonial discourses. Boundary 2, 333-358.

Orner, M. (1992). Interrupting the calls for student voice in "liberatory" education: A feminist poststructuralist perspective. Feminisms and critical pedagogy, 74-89.

Paechter, C. (2003). Learning masculinities and femininities: Power/knowledge and legitimate peripheral participation. Paper presented at the Women's studies international forum. 
Parpart, J. L. (2013). Choosing silence: Rethinking voice, agency and women's empowerment Secrecy and Silence in the Research Process (pp. 34-48):

Routledge.

Salminen-Karlsson, M. (2006). Situating gender in situated

learning. Scandinavian Journal of Management, 22(1), 31-48.

Shrewsbury, C. M. (1997). What is feminist pedagogy? Women's studies quarterly, 25(1/2), 166-173.

Stanley, L., \& Wise, S. (1993). Breaking out again: Feminist ontology and epistemology (2nd ed. ed.). London: Routledge.

Weiler, Kathleen. (1991). Freire and a feminist pedagogy of difference. Harvard Educational Review, 61(4), 449-475.

Wenger, E. (1999). Learning as Social participation: Why we must change our assumptions about how we learn and share knowledge. Knowledge Management Review, 1(6), 30-33.

Wenger, E. (2010). Communities of practice and social learning systems: the career of a concept Social learning systems and communities of practice (pp. 179-198): Springer.

Wenger-Trayner, E., \& Wenger-Trayner, B. (2015). Communities of practice. A brief introduction. Retrieved from http://wengertrayner.com/introduction-to-communities-of-practice/ 